WIENER SLAVISTISCHES JAHRBUCH, Band 56/2010, 61-81

(C) 2010 by Österreichische Akademie der Wissenschaften, Wien

FREDERIK KORTLANDT

\title{
Balto-Slavic accentuation revisited
}

There is every reason to welcome the revised edition (2009) of Thomas Olander's dissertation (2006), which I have criticized elsewhere (2006). The book is very well written and the author has a broad command of the scholarly literature. I have not found any mistakes in Olander's rendering of other people's views. This makes the book especially useful as an introduction to the subject. It must be hoped that the easy access to a complex set of problems which this book offers will have a stimulating effect on the study of Balto-Slavic accentology.

The purpose of the following observations is twofold. On the one hand, I intend to show that what the author evidently regards as his main result, the "mobility law", cannot be accepted because it is incompatible with the data. On the other hand, my aim is to pinpoint the essential differences between Olander's theory and mine (e.g. 1989a, 2005b, 2008a) in order to clarify where progress can be made. In the following, bracketed numbers which do not denote the Lithuanian accent classes (1) through (4) will refer to the pages of the book under discussion (Olander 2009).

The origin of the mistaken analysis which has resulted in Olander's "mobility law" must be sought in his reconstructions of Proto-Indo-European and Proto-Slavic. Following the German (Brugmannian, pre-structuralist) tradition, Olander reconstructs five short and five long vowel phonemes $*_{i},{ }^{*} e, *_{a},{ }^{*} o,{ }^{*} u,{ }^{*} \bar{i},{ }^{*},{ }^{*} \bar{a},{ }^{*} \bar{o}$, $* \bar{u}$, of which $* i$ and $* u$ had non-syllabic variants which were "probably in complementary distribution" but are nevertheless distinguished in the reconstructions, four resonants * $r, * l, * m, * n$ with "syllabic realisation between consonants" distinguished by a ring underneath, "four fricatives" ${ }^{*},{ }^{*} h_{1}, * h_{2}, * h_{3}$, the latter of which had "vocalic variants" $*_{\partial_{1}}, *_{\partial_{2}}, *_{\partial_{3}}$, three labial stops $*_{p},{ }^{*} b,{ }^{*} b^{h}$, three dental stops $* t,{ }^{*}$, $* d^{h}$, three palatal stops $* \hat{k}, * g,{ }^{2} g^{h}$, three velar stops $* k, * g,{ }^{h}$, and three labiovelar stops $* k^{w}, * g^{w}, * g^{w h}(83)$, i.e. a total of 10 vowels, two of which had consonantal realizations, and 23 consonants, seven of which had "vocalic variants". This large and complex phonological system, which allows an impressive number of $425 \mathrm{CV}$ and $10625 \mathrm{CVC}$ sequences, is clearly at variance with Olander's professed "methodological choice to attach considerable weight to simplicity" of reconstructed syn- 
chronic systems (2009: 4). The larger the inventory of the input, the easier it is to "explain" almost any actually occurring word form. In my view, the great merit of the laryngeal theory is that it enables us to reduce the inventory of Proto-Indo-European phonemes in a substantial way. Olander recognizes that long vowels "had a very limited distribution in the proto-language; most long vowels in the Indo-European languages are the result of contraction of a short vowel with a following laryngeal" (83), which raises the question if they must be reconstructed at all. The same holds for the "consonantal and vocalic realisations" of $*_{i}, * u,{ }^{*},{ }^{*} l,{ }^{*} m, *_{n}$ and the laryngeals. In my view, syllabification developed in the separate branches of IndoEuropean, e.g. Latin sine and Tocharian B snai 'without' from PIE *snHi, where the laryngeal was consonantal in Latin and became syllabic in Tocharian. Interestingly, Olander's definition of syllables is language-specific (13), and I agree: there is no such thing as a universal syllable. From a phonological point of view, the coloring of vowels by contiguous laryngeals also does not go back to the proto-language (cf. Lubotsky 1989, 1990). The velar stops developed in dialectal Indo-European times from depalatalization of the palatovelars and delabialization of the labiovelars of the proto-language (cf. Steensland 1973). Thus, I reconstruct two vowels $*_{e}$ and $*_{o}$ with lengthened variants $*_{\bar{e}}$ and $* \bar{o}$ in monosyllables and before final resonants (cf. Wackernagel 1896: 66-68), six resonants $*_{i}, *_{u}, *_{r}, *_{l}, *_{m}, *_{n}$, three laryngeals *?, $* \zeta$ * $\zeta^{w}$, one fricative $* s$, and twelve stops. As I have argued elsewhere (e.g. 1985b), the "voiceless" and "voiced aspirated" stops were fortes and lenes, respectively, and the "plain voiced" stops were glottalized. While Olander's reconstruction does not allow for a chronology of dialectal Indo-European developments, such a chronology is an essential part of my reconstructions.

In contrast with the large inventory of Proto-Indo-European phonemes, Olander reconstructs a minimal system for Proto-Slavic: six stops ${ }^{*} p,{ }^{*} b,{ }^{*} t,{ }^{*} d,{ }^{*},{ }^{*} g$, three fricatives $*_{s}, *_{z}, *_{x}$, four resonants $*_{m}, *_{n}, *_{l}, *_{r}$, four short vowels $*_{a}, *_{e}, *_{i}, *_{u}$ and four long vowels $*_{\bar{a}}, *_{\bar{e}}, *_{\bar{l}}, *_{\bar{u}}(127)$. The two semivowels $*_{j}$ and $*_{w}$ "were probably variants" of the vowels $* i$ and $* u$ and "did not have independent phonological status" (ibidem). Since Olander reconstructs neither ${ }^{*} w$ nor $* H$ for this stage, it remains unclear how he accounts for the difference between e.g. zvěrb 'beast' and $z$ zvati 'to call'. The smaller the inventory of the output, the easier it is to "explain" almost any word form thus reconstructed. Olander dismisses all instances of shortened "long" vowels, as in Serbo-Croatian jägoda and Czech jahoda 'strawberry', and all instances of lengthened "short" vowels, as in SCr. bërē 'gathers' and Czech vile 'will', as recent developments and does not take them into consideration in his analysis. This greatly simplifies his task because accounting for the new quantitative distinctions such as between $*_{a} a$ and $*_{\bar{a}}$ and between $*_{o}$ and $*_{\bar{o}}$ is by far the trickiest part of Slavic accentology. It also puts him on the wrong track because his "mobility law" is irreconcilable with the quantitative reflexes of vowels and diphthongs in Slavic. The same holds for his early date of Dybo's law (ibidem), for which he offers no argumentation. Note that Olander's reconstruction of "Proto-Sla- 
vic" corresponds to stage 6.0 of my chronology (e.g. 1989a: 47, 2005b: 119), which differs from his system in the presence of a glottal stop. The loss of the glottal stop gave rise to shortened "long" vowels (stages 7.13 and 9.2 of my chronology) and paved the way for the rise of lengthened "short" vowels (my stages 7.15, 8.1, 8.2 and 8.8). Thus, Olander omits a large and essential part of the evidence.

There is a lot of misunderstanding resulting from terminology and definitions in Balto-Slavic accentology. It is therefore appropriate that Olander devotes an introductory section to these problems (7-14). Unfortunately, his choices are not always felicitous. His $\bar{s} s$ - and $\bar{u} s$-stems are actually $i H$ - and $u H$-stems with a sigmatic nominative. He regards stems in semivowels and laryngeals as vowel stems, not consonant stems. His "desinence" refers to the complex of stem-forming suffix and case marker while his "ending" refers to the case marker only, which is the opposite of common practice. He defines Proto-Indo-European as "the language spoken at the end of the period that precedes the oldest innovation not shared by all (known) IndoEuropean languages", which corresponds to stage 2.0 of my chronology, not to stage 3.0 , which is the end of the dialectal Indo-European period preceding the earliest Balto-Slavic innovations. This is at variance with his reconstruction of the "ProtoIndo-European phonological system" (83), which represents a subphonemic diasystem between my stages 2.1 and 2.2 (see above). His Proto-Balto-Slavic and his Proto-Baltic correspond to my stage 5.0 (see also Kortlandt 2008b). His Proto-Slavic is defined as the stage immediately before the monophthongization of oral diphthongs, which took place at my stage 6.5 (e.g. 1989a: 48, 2005b: 119). In fact, his reconstructed "Proto-Slavic" phonological system (127) corresponds to my stage 6.0, before the umlaut (6.1) and the first palatalization of velars (6.2). This is long before the earliest Slavic dialectal developments, which arose around stage 7.0 (cf. Kortlandt 2003b: 231), and many centuries before the last common Slavic innovations and the disintegration of the common language (stage 10.0).

Olander's discussion of the prosodic terminology (10-14) is also less than satisfactory. He states that Štokavian "in a superficial analysis has contrasting tones, e.g. gen. sg. sèla with rising tone vs. nom.-acc. pl. sëla with falling tone. In a somewhat deeper analysis, however, where rising tone is interpreted as accent on a following syllable, i.e. se'la vs. 'sela, Štokavian may be viewed as a non-tonal language". In fact, the "somewhat deeper analysis" is simply wrong because non-initial falling tones are frequent in Štokavian and the normative system is artificial and probably never existed in any authentic dialect (cf. Vermeer 1985). Olander defines the term "accented" as referring to "the prominent syllable of a word in prosodic systems where no more than one syllable of a word is prominent relative to its neighbouring syllables. [...] Unaccented word-forms are found in languages like Vedic and Japanese [...]. Automatic, i.e. non-distinctive, prominence of a certain syllable in a phonological word" is referred to as "ictus", which "in the case of unaccented words" falls on the initial syllable (11). This again is contrary to common practice, where ictus ('beat') refers to dynamic prominence and accent (= $=\pi \rho o \sigma \omega \delta i \alpha$ 'pitch') 
to tonal characteristics. It would be preferable to restate these definitions in terms of High and Low tone (where I use capital letters with reference to tone levels), making clear that the "automatic" Low tone on the initial syllable of an "unaccented wordform" is in fact distinctively Low as opposed to a High tone on the initial syllable of an "accented" word form with initial stress. Olander's identification of the Vedic and (Tokyo) Japanese systems as having "unaccented word-forms" is a source of confusion. Vedic has a full-fledged tone system with any sequence of High and Low tones, e.g. RV 1.1.6 távét tát satyám on one hand and 10.75.5 imám me gange yamune sarasvati sútudri on the other (cf. Kortlandt 1986: 156). On the other hand, contrary to Olander's presentation (12), Japanese hasi 'edge' and hasi 'bridge' are homophonous (Low-High) in the Tokyo dialect, where a following enclitic particle is High after 'edge' but Low after 'bridge', just as Russian kod 'code' and kot 'tomcat' are homophonous but differ accentually in the genitive kóda versus kotá. While Vedic has distinctive tone, Tokyo Japanese has only lexical pitch accent. A final source of confusion is the term "circumflex" (14), which usually refers to a falling tone in Slavic and to the absence of an "acute" in Baltic. While I am happy to see that Olander has accepted my view that the Balto-Slavic acute can be identified as glottalization, I am sorry that he has not (yet) seen why glottalized vowels must have remained distinct from earlier long vowels in Slavic.

As is clear from Olander's Table 2 (46), the two pillars of modern Slavic accentology are Stang's demonstration (1957) that Saussure's law did not operate in Slavic and Dybo's establishment of a progressive accent shift from non-acute nonfalling vowels in flexion (1962) and derivation (1968). The views of authors who do not accept these two fundamental discoveries (including Klingenschmitt and Stankiewicz) are by now primarily of historical interest. The major question which remains, in Olander's framework, is whether original accentual mobility was inherited from the Indo-European proto-language or developed in Balto-Slavic times. While


$\theta v \gamma \alpha \tau \rho o ́ \varsigma$ 'daughter' and Vedic àtmáa , ātmấnam, tmánā, tmáne 'soul' can hardly be doubted, the absence of accentual mobility in original $o$-stems is equally certain. Olander challenges the classic view that vowel stems adopted the accentual mobility of the consonant stems ("Pedersen's law") and claims that the earlier accentual mobility which is reflected in alternating ablaut grades had almost wholly been eliminated in the Indo-European proto-language already. Here I disagree: nobody would maintain on the basis of the Welsh and Armenian evidence that the accent was fixed on the penultimate syllable in the proto-language, and the same holds true for the fixation of the stress in Vedic and Greek, where many traces of accentual mobility have been preserved. Indeed, it seems to me that the alternating ablaut grades provide a much more faithful piece of evidence than the attested place of the ictus, which does not go back more than 2500 years at most. Olander's analysis in terms of syllables is less appropriate than an analysis in terms of tone-bearing morphemes, where e.g. Greek $\theta v \gamma \alpha \tau \varepsilon \rho \rho \alpha$ is stressed on the suffix and $\theta v \gamma \alpha \tau \rho o ́ \varsigma$ on 
the desinence. In my view, the alternation between stem-stressed and end-stressed forms can easily have been generalized from consonantal to vocalic stems. The argument that "the consonant stems constitute an unproductive group of words that are gradually disappearing in Baltic and Slavic" and that they cannot therefore "have influenced the large and productive group of vowel stems in such a profound manner as an imitation of the accent curves would imply" (51) is not valid because we are dealing with the earliest Balto-Slavic developments here, taking place at a stage when consonantal stems may still have been in the majority. Note that the $\bar{a}-, \bar{e}-, \bar{l}-$, $\bar{u}-, i$ - and $u$-stems were also consonant stems at the outset. While I agree with Olander that analogical change requires a motivation and that a "typical example of a motivation would be the simplification of a complicated system" (50), I think that a morphological generalization is no less probable than the automatic fixation of the stress on a non-initial syllable. Thus, I stick to Pedersen's law; for the oxytonesis see below.

Olander states that the analogical changes which account for the lateral mobility in Slavic paradigms "constitute the backbone of Kortlandt's theory of Balto-Slavic accentuation" (49). This is not correct. Starting from the assumption that the lateral mobility was not directly inherited from the Indo-European proto-language but could have developed by analogy with the consonant stems, this was not my major concern. The backbone of my theory is the thesis that the Balto-Slavic acute was a glottal stop which developed from the Indo-European laryngeals and from Winter's law and is reflected as glottalization in Latvian and Lithuanian and that the gradual loss of this glottal stop accounts for the development of vocalic timbre and quantity distinctions in Slavic. The red thread which runs through these developments is a series of sound changes: Hirt's law (4.1), Winter's law (4.3), retraction of the stress from final open syllables (4.4), loss of the glottal stop in pretonic and post-posttonic syllables (5.3), loss of the glottal stop in the remaining posttonic syllables (7.13), Van Wijk's law (7.15), contractions in posttonic syllables (8.1), retraction of the stress from final jers (8.2), Dybo's law (8.7), lengthening of short falling vowels in monosyllables (8.8), loss of glottalization in stressed syllables (9.2), Stang's law (9.3), shortening of long falling vowels (9.4), lengthening of short vowels and retractions of the stress in the daughter languages (10.4-10.12). These phonetic laws were followed by analogical levelings which account for the distribution of accent, timbre and quantity in the attested Slavic material. In this framework, the loss of Indo-European accentual mobility (3.1) was never intended to be more than a working hypothesis in order to simplify the analysis. As more traces of Indo-European accentual mobility in Balto-Slavic became clear to me (cf. Kortlandt 1985c, 1987, 1989b, 1997b, 2000, 2001), I have finally abandoned this hypothesis (2009), see below.

Olander makes a distinction between long and hiatal final syllables, the latter "containing two contiguous vowels, possibly separated by a laryngeal" (8). In Greek, "sequences of two vowels behave alike whether separated by a laryngeal or 
not”, e.g. dat.sg. $\dot{\alpha} \gamma \rho \tilde{\varphi}$ 'field' < *oei and $\varphi v \gamma \tilde{\eta}$ 'flight' < *aHai (89). I agree that the Greek circumflex reflects a sequence of two vowels possibly separated by a laryngeal here and reconstruct $*_{-o}$ e $e i$ and $*_{-a}$ ?ai $<*_{-} e$ ei, similarly dat.sg. oí $\kappa \omega$

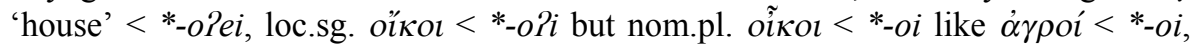

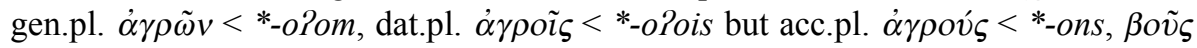

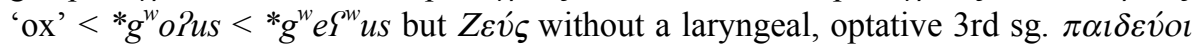
'educate' $<*_{-o \bar{l}}<*_{-o i P t}$, 3rd pl. $\tau \imath \theta \varepsilon \tilde{\imath} \varepsilon v$ 'put' $<*_{-}$-ePiy- but aor. $\lambda \dot{v} \sigma \varepsilon \iota \alpha v$ 'loosen' < *-eiy- (cf. Kortlandt 1992). In Indo-Iranian, intervocalic laryngeals were lost at an early stage with contraction yielding long vowels but were later restored at morpheme boundaries after the rise of new intervocalic laryngeals from the vocalization of the syllabic nasals, e.g. *ma?as 'moon' < *me?ns, *va?atas 'wind' <* Fue?ntos, which was followed by the rise of the new gen.pl. ending *a?am (cf. Kortlandt 2007b). The same introduction of the formative suffix before the PIE ending *-om is found in Germanic, where the laryngeals were lost at an early stage, e.g. Gothic -o< *-āom, later again in Old High German -ōno, similarly in Sanskrit -ānām, -īnàm,


this explanation as "quite unnatural" (78) is quite incomprehensible to me. The original PIE ending *-om is attested in Slavic - $\bullet$, Lith. $-\iota$, Prussian -on, and in Germanic, Celtic, Italic, Indo-Iranian and Anatolian (cf. Kortlandt 1978b). I am happy to see that Olander has accepted (90) my derivation of the Lith. nom.pl. ending *-ie from $\left.*_{-a} a i<*_{-} e\right\}-i$ (without giving the argumentation for this reconstruction, cf. Kortlandt 1993). I cannot accept Olander's derivation of Slavic - $i$ from *-oi and *-ai (90), which is at variance with loc.sg. *vblcě 'wolf', for which he arbitrarily assumes replacement by the ending of the $\bar{a}$-stems, and with the pronominal forms mbné, tebě, sebě and 1st sg. vědě 'know', which he does not discuss (cf. Kortlandt 1983: 178). In my view, oral and nasal diphthongs were raised before final $*_{-s}$ (stage 5.9 of my chronology), e.g. imperative nesi 'carry' < *-oi?s, inst.pl. raby 'slaves' <

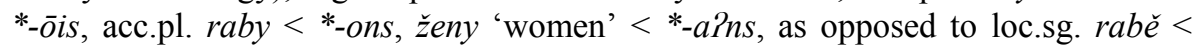
$*_{-o i}$, dat.sg. rabu $<*_{-}-\bar{i}$, Old Russian nesa 'carrying' < *onts, soft ending -ja <

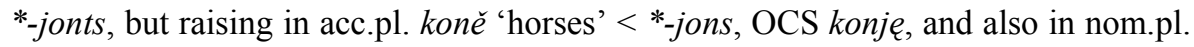

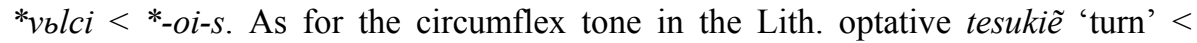
$*_{-o i ? t}$, as opposed to the acute of Slavic $*_{n e s i}<*_{-}$oi?s, I assume that final $*_{-}$?t merged with preglottalized $*_{-}-*_{-} t$ (as in Latin quod and Old High German $h w a z$ 'what') before the latter was lost in Balto-Slavic times (my stage 3.7). This development is reminiscent of the Indo-Iranian loss of a laryngeal before a preglottalized stop followed by another consonant which was established by Lubotsky (1981), e.g. in Vedic pajrás 'firm' < *pe९ğros beside pấjas 'frame' < *pe९gos.

It has long been recognized that the traditional PIE voiceless and voiced aspirated stops could not co-occur in the same root, so that roots of the type *te(r) $d^{h}$ and $*^{h} e(r) t$ - are excluded. It follows that the distinction between fortes and "aspirates" was a prosodic feature of the root as a whole, which may be called "strong" (or "high") if it contained e.g. * $t$ and "weak" (or "low") if it contained e.g. 
$* d^{h}$. Dybo has shown (1968) that Baltic and Slavic morphemes can be divided into two prosodic classes, viz. "strong" ("high", "dominant") morphemes which attract the accent and "weak" ("low", "recessive") morphemes which repel the accent, and that the stress falls on the first strong morpheme of a word form (cf. Olander 2009: 33). This system can be explained in a straightforward way from an earlier system with distinctive High and Low tones. Lubotsky has shown that there is a highly peculiar correlation between Indo-European root structure and accentuation (1988: 170), which again points to an earlier level tone system. I have proposed (2004) that we must rather start from "strong" and "weak" syllables which originated from an Indo-Uralic consonant gradation. In any case, the prosodic system reconstructed for Proto-Indo-European was very close to the system actually attested in Vedic Sanskrit. The question whether "each constituent morpheme of a Proto-IndoEuropean word had a surfacing distinctive high or low tone, which would render the accent redundant, or that the tones were distinctive only at a pre-stage of Proto-IndoEuropean, having become redundant in the proto-language because of the distinctive accent" (Olander 2009: 85) receives the same answer as in the case of Vedic, depending on one's theoretical predilections (see above).

Holger Pedersen made a distinction between "proterodynamic" and "hysterodynamic" accentual mobility (1926: 25, 1933: 21), the former between root and suffix and the latter between suffix and desinence, and stated that these accent movements "n'ont joué aucun rôle pour le développement lituanien" (1933: 22). The idea that there were two types of PIE accentual mobility was elaborated by Kuiper (1942) and other scholars, most consistently by Beekes (1985), who demonstrated that the nom.sg. form of the hysterodynamic paradigm was originally stressed on the root, not on the suffix, and that the proterodynamic and hysterodynamic paradigms have a common origin. Olander again follows the German (Hoffmannian) tradition, using "-kinetic" for "-dynamic" (92) and disregarding Beekes' findings. He dismisses "the presence of ablaut alternations in the root of a word in one or more languages as an indication of paradigmatic mobility in that word in the proto-language" (93), which puts an end to the discussion. He accepts Rasmussen's idiosyncratic view that the "distribution of $*_{-} e$ - and $*_{-o \text { - }}$ in the thematic suffix was not dependent on the accent but on a following segment, $*_{-} e$ - and $*_{-}-O$ - appearing before an unvoiced and voiced segment respectively" (94). Disregarding Beekes' argumentation (1995: 128 f.), he ignores the evidence for paradigmatic mobility in the $\bar{a}$-stems (95) and dismisses the evidence in the $i$ - and $u$-stems (96). He rejects the accentuation of Greek $\theta v \gamma \alpha \dot{\tau} \tau \eta \rho$ and $\mu \eta \dot{\tau} \eta \rho$ as secondary (72 f.) without mentioning Lycian kbatra 'daughter' < ${ }^{*} d^{h}$ uegStr (cf. Kloekhorst 2008: 904) and attaches no importance to the accentual

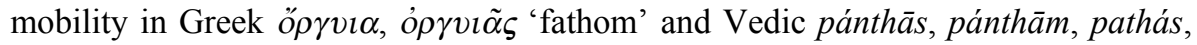
pathișu 'path' (97). In my view, Vedic pātár- 'protector' and pitár- 'father' represent a single PIE paradigm with nom. *peStr, acc. *pSterm, gen. *pStros, cf. Maltese missier 'father' < French monsieur < mon seigneur 'my lord'. I shall not discuss the accentuation of verbal paradigms here. 
Since "the curves of the Proto-Baltic mobile paradigms are virtually reconstructed on the basis of Lithuanian material only" (101), Olander does not discuss Proto-Baltic. I have argued that Proto-Baltic and Proto-Balto-Slavic are the same thing because there are no common innovations of West and East Baltic which were not shared by Slavic (e.g. 1977, 2008b). Olander does not discuss métatonie douce in Lithuanian (102) and does not even mention métatonie rude, nor metatony in Latvian. In my view, the rise of metatony coincides with the rise of syllabic tones in East Baltic (e.g. 1977: 324-328, cf. also Derksen 1996). Olander regards the accentuation of secondary case forms in $-n(a)$ and $-p(i)$ as evidence for "unaccented word-forms" in Lithuanian, e.g. illative galvõn, galvósna 'head(s)', allative darbóp 'work' (103). I agree with Seržants' view (2004) that the original accentuation of the illative was that of the accusative (cf. Kortlandt 2005a). The Latvian locative represents the illative, not the inessive (cf. Vanags 1994), and also has the accentuation of the accusative. The short vowel of Lith. nèveda 'does not lead' shows that the accentuation of this form is more recent than the lengthening in vẽda, which is limited to Lithuanian (cf. Kortlandt 1977: 326), and cannot therefore go back to Proto-Baltic times. Nieminen's law (105) represents two distinct developments: an East Baltic retraction from final $*_{-} \grave{a}$ and a later retraction from final $*_{-a} a$ in Lithuanian (cf. Derksen 1996: 96-128 and 229-232). The "analogical spread of accentual mobility at the expense of the immobile paradigms" in Lithuanian (107) is largely reversed in the modern language. The Old Lithuanian mobile accentuation in žinóti 'to know' (108) is supported by the Slavic evidence (cf. Kortlandt 1985c). Accentual mobility is also found in Lith. duodãs 'giving', Latvian duômu 'I give', sêžu 'I sit', èimu 'I go' (Varakḹni, cf. Kortlandt 1977: 321, 323, 327), and Slavic athematic verbs. Olander has accepted (114 f.) my view that original PIE long vowels are non-acute in Balto-

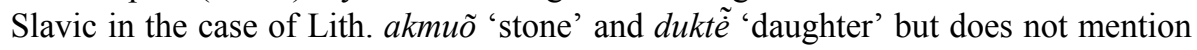
the evidence of Latvian âbuõls 'apple', SCr. žêrāv, Czech žeráv 'crane' (e.g. Kort-

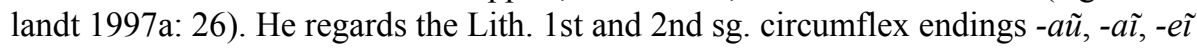
as "exceptions to Leskien's Law" (115) without mentioning that they are acute in the Žemaitian dialects and regularly became circumflex in Aukštaitian. He rightly concludes that Saussure's law was limited to Lithuanian (116 f.) but does not mention the chronological argument (cf. Kortlandt 1977: 327). Olander rejects "Kortlandt's Law" (124 f.) without explaining the accentuation of such forms as Old Prussian semmēe, wedde, Lith. žẽme 'earth', vẽde 'led', also OPr. twaiā, twaiāsmu, swaī̄smu, tenn̄a , tennēismu, tennēison, tennēimans, gennāmans, widdewū, widdewümans. He adduces the absence of a macron in such words as OPr. deiws 'god', deinan 'day' as evidence for "unaccented word-forms" (125 f.) without explaining the presence of a macron in e.g. mērgan 'maid', āntran 'other', äusins 'ears' (cf. Kortlandt 2006: 363).

Now we turn to Slavic. "If a word-form containing only syllables with low pitch, i.e. an unaccented word-form, was followed by an enclitic, the enclitic received an automatic ictus" (128). This is Dolobko's law (my stage 7.2). "If there was no 
enclitic, the phonological word, i.e. the morphological word-form preceded by zero or more proclitics, received an automatic ictus on the initial syllable", i.e. a distinctive Low tone (my stage 6.10). "The unaccented word-forms, which at later stages of Slavic often received initial accentuation, were realised differently from initially accented word-forms", viz. by the distinction between Low and High tone. Apart from the unfortunate terminology ("unaccented" = Low tones only, "automatic ictus" = High tone on an enclitic but Low tone on an initial syllable, "initially accented" = High tone on an initial syllable), Olander and I seem to be in agreement here. The phrase "which at later stages of Slavic often received initial accentuation" is confusing because we already have "automatic ictus" and distinctive tone on the initial syllable at this stage, Low tone being regularly reflected as falling tone in Serbo-Croatian. Olander's biggest mistake (cf. Kortlandt 2006: 364) is his assumption that the distinction between glottalized and non-glottalized vowels had disappeared at this stage, the former yielding "long" vowels. As a result, he is unable to account for such quantitative distinctions as $*_{a} a$ versus $*_{\bar{a}}$ in Slavic. Contrary to Olander's statement (128), the Proto-Slavic prosodic system was not typologically similar either to that of Vedic (which had High and Low particles and syntactic conditioning of tone alternations) or to that of Tokyo Japanese (where accented Low tones surface as High tones). Greatly adding to the confusion, Olander now changes his terminology: "syllables are acute if they are accented and contain a long vowel, circumflex if they are unaccented or contain a short vowel" (129). Disregarding the instances where a long vowel lost the stress to the following syllable as a result of Dybo's law, e.g. Czech bily' 'white', poutnik 'traveler', tráva 'grass', trávni 'grassy', trávnik 'pasture', národ 'people', zákon 'law', trouba 'trumpet', zábava 'fun, party', útroba 'intestine', as opposed to jazyk 'tongue', malina 'raspberry', chladný 'cold', těžký 'heavy', suchý 'dry', ruka 'hand', ruční 'hand-', ručnik 'towel', sukno 'cloth', humno 'threshing-floor', where an original pretonic long vowel was shortened, Olander reconstructs long vowels in "Proto-Slavic" *dārga a 'road', *gālwā 'head', acc. *gālwān for the short vowels of SCr. dräga, gláva but obl.pl. glàvama, adj. glàvnī, Czech hlava, hlavu, hlavní, Polish droga, głowa, glowę, Upper Sorbian dróha, hłowa, also long *ā in *gena 'woman' for SCr. žèna, dial. ženä, and in inst.pl. *genāmī, SCr. žènama, Slovene ženâmi $<$ *ženàmī (cf. Kortlandt 2005b: 124). Similarly, Olander does not account for the quantitative difference in the suffix between Czech pekar̆ 'baker' and rybár 'fisherman' or between SCr. dvòrište 'yard' and blätǐšte 'mud-pit' or Čakavian potēgnüt 'to pull' and dvïgnüt 'to lift' (cf. Kortlandt 2005b: 129).

According to Šaxmatov's law (1915: 84), medial syllables lost a falling tone to a preceding short vowel but not to a preceding long vowel, where the falling vowel was shortened instead, e.g. SCr. prödāli 'sold' < *prodâli, náuka 'science' < *nâuka. We now know that the latter formation received the medial stress as a result of Dybo's law (cf. Kortlandt 2005b: 122). I have subsumed the former type under Pedersen's law because it represents a retraction of the stress in mobile paradigms. 
Šaxmatov's law must not be confused with Stang's law, according to which the stress was retracted from long falling vowels after Dybo's law (cf. Kortlandt 2005b: 123). Olander redefines Šaxmatov's law as "an accent retraction from a word-initial syllable with falling tone to a proclitic or prefix" (130). He regards the retracted accent as "the result of the automatic ictus placement rule inherited from ProtoBalto-Slavic" (ibidem). The problem with this interpretation is that the retraction of the stress and the rise of distinctive tone (my stage 6.10) must have been more recent than the generalization of accentual mobility in the masculine $o$-stems which did not have an acute root vowel ("Illič-Svityč's law", stage 6.9), e.g. in SCr. zûb 'tooth', Greek $\gamma o ́ \mu \phi o \varsigma$ (cf. Kortlandt 2005b: 119), which was conditioned by the identity of the paradigms (b) and (c) except in the oblique plural case forms and by the absence of barytone forms with an acute root vowel in paradigms with mobile stress after Meillet's law (stage 5.4), while original barytone neuters are continued as masculine $o$-stems of paradigm (b). Olander evidently does not appreciate the problem when he states that "substantial coincidence of the accent curves of two paradigms is not a necessary prerequisite for the transfer of lexemes among the paradigms" (145, cf. also Kortlandt 2006: 364). Note that in Olander's reconstruction only the gen.pl. and inst.pl. forms of the paradigms (b) and (c) have the same accentuation while the original (i.e. pre-Hirt) barytone masculines and barytone neuters only differed in the nom.pl. and acc.pl. forms. It appears that the alleged paradigm (d) reconstructed by some scholars (135) never existed (cf. Langston 2007 and Kortlandt 2007a: 231 f.).

Olander objects to my view of Meillet's law as an analogical elimination of glottalization from the barytone forms of mobile paradigms (stage 5.4) after the phonetic loss of glottalization in pretonic syllables (stage 5.3), e.g. in SCr. acc.sg. glâvu, Lith. gálvq, that such a development is unexpected in $o$-stem singularia tantum (131). He does not mention SCr. mäti 'mother', which combines an acute root vowel with accentual mobility (cf. Jurišić 1973: 116) and thereby shows that Meillet's law must have been an analogical development. As I pointed out earlier (2006: $363 \mathrm{f}$.), the high frequency of pluralia tantum with derived singulars is characteristic of Balto-Slavic, e.g. Lith. mèsà 'meat', taukaĩ 'fat', Latvian miesa, OPr. mensā, crauyo 'blood', Slavic męso '(piece of) meat'. Olander redefines Stang's law (my stage 9.3) as a retraction of the accent "from short medial diphthongs, from reduced vowels in weak position, and from contracting syllables" (131). This is quite unsatisfactory, first of all because the retraction from weak jers yielded a different reflex and therefore belongs to a different chronological layer (e.g. stage 8.2 of Kortlandt 2005b: 122), secondly because "short medial diphthongs" include $*_{-i n}$, $*_{-i} k-$-, ${ }_{-i} \bar{n}$-, from which the accent was not retracted to (b) roots (cf. Dybo 1968), and do not include e.g. loc.sg. $-\bar{u}<*_{-} \bar{e} u$ and inst.pl. $-\bar{y}<$ *-ois, from which the accent was retracted to (b) roots but not to (c) roots, thirdly because the accent was not retracted in such contracted forms as Čakavian kopâ 'digs' < *kopàje, and fourthly because the accent was retracted from long vowels which originated from Van Wijk's law, which Olander does not mention, e.g. SCr. 
pîše 'writes', völja 'will' (stage 7.15 of Kortlandt 2005b: 121). I am glad to see that Olander has accepted (132) my derivation of $-\bar{l}$ - from athematic *-ei- in the Slavic $i$-presents, e.g. SCr. nösì 'he carries'.

I shall not discuss Olander's reconstruction of "Proto-Slavic" paradigmatic accent in detail but limit myself to a few remarks. The derivation of Slavic $-b$ from PIE *-os (135) cannot be upheld (cf. Kortlandt 1983: $181 \mathrm{f}$. and Vermeer 1991). Contrary to Olander's statement (136 f.), the OCS verbs jesmb 'am', damb 'give' and jamb 'eat' had final stress before Dybo's law, as is clear from the long rising

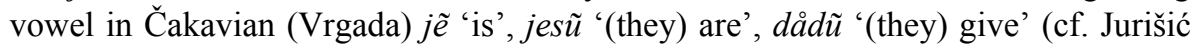
1973: 24, 42), (Hvar) jé, jesú, (Novi) jé, sú, dá, Posavian dādũ, Slovene dá, dadó, jẹ, jedó, also vé, vedó 'know'. The verbs imamb 'have' and *zbnamb 'know' also had mobile stress (cf. Kortlandt 1985c). The sigmatic aorist had fixed stress on a nonacute long vowel, e.g. SCr. donijeh 'I brought', inf. donijeti with the long vowel of the aorist beside nèsti 'to carry', similarly (Dubrovnik) rïjet beside rèci 'to say' (cf. Kortlandt 2006: 365). There is no evidence for any type of change in the aorist "by analogy with the infinitive" (138). Olander does not discuss the thematicization of athematic verbs which in my opinion gave rise to accentual mobility in the thematic presents (cf. Kortlandt 2007a: 229 f.). As a result of Olander's erroneous assumption that "after Dybo's Law the glottalisation disappeared and long glottalised vowels merged with long non-glottalised vowels" (142), he is unable to explain the numerous formations where Dybo's law introduced new long vowels in pretonic syllables. He was evidently misled by Rasmussen's suggestion that the final accentuation of *notjb sì 'this night' and *nesetè 'you carry' originated from Dybo's law (142). As is clear from the final stress of Slovene gen.sg. lahkegà, dat.sg. lahkemù 'light' and from the long vowel of Slovak nesie < *nesetb (cf. Stang 1952), the final accentuation is older than Dybo's law here. The long rising vowel in Slovene inst.pl. kostmi 'bones', možmi 'men', stabri' 'pillars', Posavian sa sinovi 'with sons', and in Slovene loc.pl. možẹ́h, 3rd pl. nesó < *nesQtì also shows that the final accentuation in these forms is older than Dybo's law, which in these endings yielded a long falling vowel from which the accent was retracted in accordance with Stang's law (cf. Kortlandt 2005b: 123, Stang 1957: 70 f., 117). The quantitative difference between Slovene kònj 'horse' < *kònjb and gen.pl. gọ́r 'mountains' < *gorì shows that Dybo's law did not shift the accent onto final jers (cf. Kortlandt 2005b: 122).

I can also be brief about Olander's reconstruction of Proto-Balto-Slavic, which is an intermediate stage between his "Proto-Indo-European" and his "Proto-Slavic". His Proto-Balto-Slavic phonological system (144) differs from mine (stage 5.0 of my chronology) in the absence of a fifth short vowel ${ }^{*} o$, phonemic $* j, *_{w}$ and glottal stop *?, and in the presence of "unaccented word-forms". My primary reason for rejecting the latter category (apart from the terminological confusion, see above) is the discrepancy between the Slavic accentual mobility between pre-phrasal and phrase-final syllables and the Lithuanian accentual mobility between pre-radical and word-final syllables, both of which originated after specific developments limited to 
the separate branches of Balto-Slavic (cf. already Kortlandt 1978a: 73-75). Olander ignores the fact that PIE lengthened grade vowels are never acute and (unlike the acute vowels) did not lose their length when the new timbre distinctions arose in Slavic (e.g. Kortlandt 1985a, Vermeer 1992). He does not discuss the dozens of instances which I have adduced but limits himself to two isolated examples "suggesting that plain long vowels merged prosodically with long vowels of laryngeal origin and long vowels from Winter's Law" (148). The first example is Lith. žverris (3), Slavic zvěrb (c) 'beast', which must be reconstructed as *źwe?r- (cf. Derksen 2008: 550). The second example is Lith. várna (1), SCr. vräna (a), Upper Sorbian wróna < *wor?na? 'crow' (cf. Derksen 2008: 528), which Olander regards as a vrddhi formation of Lith. varnas (4), SCr. vrân (c) 'raven' (147) though the word pair clearly represents an alteration of the corresponding forms in Latin cornix ,

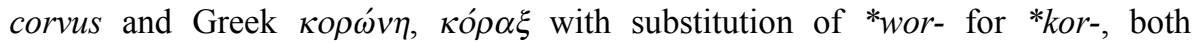
meaning 'burn', cf. also Lith. šir̃vas 'grey', mulvas 'reddish' beside Russian sérna (a) 'roe deer', Latvian mệns 'black', OPr. sirwis, Greek $\mu \bar{\varepsilon} \lambda \bar{\alpha} \varsigma$ (cf. Kortlandt 1985a: 121). Just for the record I mention one of the very few printing errors in the book under discussion: Lith. "nešás" $(154,260)$ must be corrected to nešą $(183)$.

Now we come to Olander's "Mobility Law" (156): a High tone on a word-final mora became Low in Balto-Slavic. This is an improvement in comparison with his earlier formulation (2006: 133) but presupposes an ad hoc oxytonesis in VHV sequences, where the accent shifted from the first to the second mora while it remained on the first mora of long vowels and diphthongs (156). As a result of the mobility law, end-stressed word forms became "unaccented" and received an automatic Low tone "ictus", either on the final syllable before an enclitic particle or (if there was none) on the first proclitic element or initial syllable of the phonological word (157). This is a peculiar compromise satisfying neither the Slavic mobility between pre-phrasal and phrase-final syllables nor the Lithuanian mobility between pre-radical and word-final syllables. The rule does not explain the accentuation of case forms in *-s, e.g. Lith. širdìs 'heart', lietùs 'rain', šaltàsis 'the cold one', arklỹs 'horse', gen.sg. galvõs, sirdiẽs, žveriẽs, dešimtiẽs 'ten', lietaũs, dukter̃s, nom.pl. širdys, lietūs, dùkterys, nor langaĩ 'windows', inst.sg. širdimì, lietumì, gen.pl. langũ, galvũ, loc.pl. akisù 'eyes', šakosù 'branches', (Old) Russian gen.sg. plotí 'flesh', smerti' 'death', desjatí (cf. Stang 1957: 87 f.), inst.sg. krugóm 'round', včerá 'yesterday', dat.pl. détjam 'children', ljúdjam 'people', loc.pl. détjax, ljúdjax, Slovene gen.pl. óvac 'sheep', dat.pl. možệm, kostệm, inst.pl. možmí, kostmí. Moreover, it does not account for the category of end-stressed neuters established by Derksen (cf. Kortlandt 2009: 77 f.), e.g. Lith. aũkštas (2) 'floor' with metatony, Czech vědro, SCr. vjèdro (b) 'bucket' with a shortened root vowel (cf. Derksen 2008: 518 f.). One cannot escape the impression that Olander's reconstruction of "Proto-Indo-European" endings is strongly influenced by the outcome of his mobility law: he accepts the Greek circumflex as evidence for a hiatal ending in dat.sg. $-\tilde{\varphi},-\tilde{\eta}(173)$, inst.sg. $-\tilde{\eta}$ (175), where the accent was retracted in Balto-Slavic, but cannot use the hiatus in 


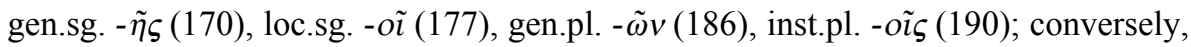
the absence of a hiatus is welcome in nom.sg. $-\dot{\eta}(167)$ but not in acc.sg. $-\eta \dot{\eta}(169)$, dual - $\omega$ (179), nom.pl. -oí (181), acc.pl. -ov́ $\varsigma(183),-\alpha ́ \varsigma(184)$. I shall not discuss the separate case forms (166-194) because I have done that earlier (2006: 366-368). Let me only add that my reconstruction of dat.pl. *-mus is based on Old Lithuanian -mus, Slavic -mb, $u$-infection in Old High German tagum and Old Norse degom 'days' (cf. van Helten 1891: 460-462), and the zero reflex in Armenian (cf. Kortlandt 2003a: 49). My retraction of the stress from this ending to the initial syllable in the $i$ - and $u$-stems at a stage (8.2) when pretonic jers in medial syllables could no longer receive the stress, e.g. in Russian détjam <*dětbmì, is supported by Slovene dánas 'today' $<* d b n b s \grave{b}$ and gen.pl. óvac 'sheep' < * owbcb̀. Note that the rise of final accentuation in the polysyllabic case forms of the $i$ - and $u$-stems must have preceded Hirt's law because accentual mobility was preserved in Slavic *klětb 'storeroom', *kyjb 'stick', *synъ 'son', *darb 'gift', *stans 'stand', cf. Lith. klëtis, kújis, sünùs, all of which would have received root stress (1) if the accent had been fixed on the second syllable before Hirt's law (cf. Kortlandt 2006: 366). This already suffices to show that Olander's mobility law cannot be maintained.

Olander regrettably follows Andersen's unfortunate suggestion to compare his mobility law with the rise of initial accentuation in the Podravian dialects of Croatia (159 f.). In these dialects, which did not share the neo-Štokavian retraction of the stress, there is a long rising vowel in krãlj je došo 'the king has come' and a short stressed vowel in rūkä me boli 'my hand aches' (cf. Klaić 1936: 182). When a phrase ends in a syllable with a long rising or short vowel, the last word receives initial stress with a falling tone on a long vowel, e.g. došo je krâlj, boli me rûka, where the accent of rukka stands for a falling tone followed by a trace of the original final stress: rûkä, similarly imperative pî̌si = pî̌sì for pǐsù 'write', krâdi for $k r a \bar{a} d \grave{\imath}$ 'steal', pîsmo for pīsmö 'letter', also müškāräc for muškāräc je döšo, ali cïgānka je kāzäla 'the man came but the gypsy woman said' and sviräće tämburãš for tamburãš će sviräti 'the mandolinist will play', with the main stress on the initial syllable of the word. Klaić emphasizes the difference between gen.sg. sëljâka for seljākä (b) 'peasant' and cìgānka (a) and between ü Beničânce for $u$ Beničāncë (b) 'to Beničanci' and $u$ Šljïvošêvce (a) 'to Šljivoševci'. It is clear that the initial accentuation did not arise from a phonetic retraction of the stress but developed as an autonomous word-initial boundary signal. Contrary to Olander's statement (160), such forms with initial accentuation are not "phonologically unaccented" but doubly accented. Olander is evidently unaware of the existence of similar systems with double accentuation in Slovak and Polish dialects along the river Orava (cf. Topolińska 1961: 86-89). In the Karelian dialects of Russian, we find variation between original final stress and new initial accentuation (cf. Ter-Avanesova 1989: 218). In Polabian and in the Pannonian dialect of the Kiev Leaflets we find both retraction of the stress from final syllables and rise of initial accentuation, which are clearly independent developments (cf. Kortlandt 1980, 1989c). None of these phenomena can be ad- 
duced as a typological parallel in support of Olander's rise of "unaccented wordforms".

In his reply to my earlier criticism (2006), Olander discards objections which "are only valid from the point of view of [Kortlandt's] own theory" because such criticism "is interesting insofar as it illustrates differences between our theories, but it does not bring to light weaknesses in my theory that need to be dealt with" (206). This will not do. Olander's interpretation of Meillet's law cannot be correct because the prosodic merger of acute and circumflex in Slavic was limited to pretonic and post-posttonic syllables while the distinction between acute and non-acute was preserved under the stress and in the first posttonic syllable, where it is reflected as short versus long in the historical languages. Similarly, Dybo's law did not shift the accent to final jers because we find a short vowel in Slovene kònj 'horse' $<* k$ konjb but a long vowel in gen.pl. gọ́r 'mountains' $<$ *gorb', and similarly in other languages. The point is that Olander's theory simply does not account for the evidence. My chief objection is not the typological improbability of Olander's mobility law but the fact that it is contradicted by the evidence. I agree with Olander that the lack of typological evidence is not crucial. As was pointed out above, contrary to Andersen's mistaken analysis, it is simply not true that a final High tone was lost in Podravian or Karelian dialects of Slavic which developed an initial High tone under the influence of neighboring languages. There is no typological parallel for Olander's phonological (as opposed to a syntactic) rise of "unaccented word-forms".

In my earlier criticism I drew attention to the following words (2006: 361):

(a) SCr. kräva 'cow', Slovak krava, Polish krowa, Czech kráva, Upper Sorbian kruwa $<$ krówa;

(b) SCr. brázda 'furrow', Slovak brázda, Polish bruzda < brózda, Czech brázda, Upper Sorbian brózda;

(c) SCr. bráda 'beard', Slovak brada, Polish broda, Czech brada, Upper Sorbian broda.

It is clear that we have a distinction between acute (a), long (b) and short (c) vowels here, all of which are reflected as $a$ in South Slavic and Czecho-Slovak and as $o$ in Polish and Sorbian. The acute vowels were lengthened in Czech and Upper Sorbian (stage 10.6) after the rise of the new timbre distinctions (stage 7.13) while they remained short in Serbo-Croatian, Slovak and Polish. In Serbo-Croatian we find a long vowel in disyllabic forms of paradigm (c) but a short vowel in polysyllabic forms and in derivatives (cf. Kortlandt 2005b: 125-128). Olander obscures the evidence by removing the pretonic vowels from the discussion through substitution of the accusative for the nominative in my examples, asserting that I do not take "the role played by the position of the accent" into account (207 f.). He reconstructs a long vowel for the short vowel in (a) and a short vowel for both the long vowel in (b) and the short vowel in (c). He relegates the discrepancy between the long vowel 
in (b) and the short vowel in (c) to a footnote, where he claims that "we do not avoid the assumption of some subsequent analogical levelling in the Slavic languages" and that in the reflexes of (c) "in most cases the short root vowel has been generalised throughout the paradigm" (208), ignoring the universal short vowel reflex in flexion and derivation except in disyllabic word forms in Serbo-Croatian paradigms, e.g. obl.pl. rùkama 'hands', rùčni 'hand-', rùchnīk 'towel', gràdskī 'urban', hlàdnī 'cold', tèškī 'heavy', sùhī 'dry', Czech ruka, ruční, ručnik, chladný, těžký, suchý (c), as opposed to SCr. tráva 'grass', trâvnī 'grassy', trâvnīk 'pasture', bïjelī 'white', pûtnīk 'traveler', Czech tráva, trávní, trávnik, bilý, poutnik (b). Pretonic long vowels in paradigm (a) are always shortened, e.g. SCr. jèzik 'tongue', màlina 'raspberry', Czech jazyk, malina, Polish język, similarly sędzia 'judge' < *sodbjà (< pre-Dybo *sodb̀ja, cf. Russian sud'já with final stress) as opposed to watroba 'liver', Czech útroba $<* \bar{Q}$ tròba, where the initial vowel lost the stress as a result of Dybo's law.

Following Holger Pedersen (1933: 22), I started from the assumption that ProtoIndo-European accentual mobility had largely been eliminated at the beginning of the Balto-Slavic period (stage 3.1). This is not only because the loss of PIE accentual mobility also affected Vedic and Greek, but especially because Illič-Svityč (1963) did not distinguish between mobile and oxytone paradigms and because I wanted to avoid circular reasoning when directly comparing Balto-Slavic with IndoEuropean accentual mobility. Dropping the assumption that accentual mobility had been lost at an early stage, I reconsidered the Balto-Slavic accent laws against the background of an independent reconstruction of Proto-Indo-European accent patterns on the basis of the apophonic alternations in the most archaic attested paradigms (2009: $76 \mathrm{f}$., cf. Beekes 1985: 150). This enabled me largely to remove the barytonesis (3.3) and the oxytonesis (3.4) from my chronology. It also opened the way to explain the origin of Dybo's "dominant" suffixes on the basis of Derksen's end-stressed paradigms (ibidem, 77-79) and thereby to reformulate Pedersen's law (3.2) as a phonetic development, eliminating Stang's counter-examples (1957: 12). This does not, however, prove that Pedersen's law was indeed a phonetic development, and I do no think that it was. When we look at accent retractions in South and West Slavic languages, we see that they are always part of a gradual process. In Bulgarian, the stress was retracted from a final short vowel to a preceding open syllable (cf. Kortlandt 1982). In Serbo-Croatian, the stress was retracted earlier from a final than from a non-final syllable, earlier from an open than from a closed syllable, earlier from a short than from a long vowel, and earlier to a preceding long than to a preceding short vowel (cf. Ivić 1958: 105). In Slovene, the stress was retracted from a final short vowel to a preceding long vowel, and later also to a preceding short vowel (cf. Kortlandt 1976: 6 f., Greenberg 2000: 120, 143). In the Pannonian dialect of the Kiev Leaflets, the stress was retracted from a final open syllable (cf. Kortlandt 1980). In Polabian, the stress was retracted from a short vowel in a final syllable (cf. Kortlandt 1989c). In Slovincian, the stress was retracted first from a final syllable to a preceding long vowel, then from a final syllable in polysyllabic word forms and 
analogically from medial syllables in paradigms with fixed stress, and later from a final short vowel in disyllabic word forms (cf. Kortlandt 1978a: 77). The fixation of the stress on the initial syllable in West Slavic languages first affected polysyllabic word forms in Polabian, Kashubian, Polish and Slovak dialects and the Pannonian dialect of the Kiev Leaflets, and end-stressed word forms in Podravian and in Karelian dialects of Russian. After the fixation of the stress on the initial syllable, it may look like this was the result of a single phonetic process, but this conclusion is clearly wrong. In view of the attested retractions of the stress in West and South Slavic languages, it seems to me that a retraction of the stress from medial syllables can more easily have been an analogical than a phonetic development and I therefore stick to the term "Pedersen's law".

While retractions of the stress can often be described as phonetic developments, the fixation of the stress on the initial syllable requires the existence of a morphosyntactic unit with an initial syllable. This renders the distinction between sound law and analogy disputable (cf. Olander 2009: 210, fn. 21). Olander finds it "difficult to see the motivation behind" (211) the Slavic extension of Pedersen's law (which he calls "Šaxmatov's Law", 130). In my view, generalization of the Low tone of pretonic syllables to barytone forms of mobile accent paradigms gave rise to Olander's "unaccented word-forms" with distinctive Low tone on the initial syllable (stage 6.10). This introduction of a distinctive Low tone is an essentially syntactic development with a perfect analogue in Vedic. It created the possibility of lexical clitics, e.g. Russian četýrnadcat' 'fourteen', (byliny) belý grudi 'white breasts', Slovincian jáu robja 'I work', Bulgarian Ćérno more 'Black Sea' (cf. already Kortlandt 1978a: 74), also Slovene gen.sg. lahkegà, dat.sg. lahkemù 'light' (Dolobko's law, stage 7.2), where the final stress marks the end of the "phonological word", as Olander calls it. The Low tone had a falling contour after a preceding High tone, as a result of which the High tone received a rising contour after a preceding Low tone. At a later stage (8.7), the rising contour shifted the High tone to the following syllable (Dybo's law). Suppression of the contour could probably be used for a contrastive interpretation, as in modern Serbo-Croatian od bräta (Low-High-Low) 'from the brôther' as opposed to regular od brata (rising-falling) 'from the brother' (cf. Ivić - Lehiste 1967: $75 \mathrm{f}$.). In Slovene, the distinctive Low tone became High when the falling contour shifted to the right while the High tone became Low, e.g. in kọst (High) 'bone' versus pót (Low) 'way' (cf. Greenberg 2007: 77 and Pronk 2009: 20). The rise of a distinctive Low tone was not an automatic consequence of the retraction of the stress to a preposition or prefix, as is clear e.g. from Russian ottúda 'from there', donél'zja 'as can be', cf. tudá, nel'zjá, also SCr. nà vrāta beside vráta (b) 'door', all of which received non-initial stress as a result of Dybo's law, similarly in the verb nàlomìm, slömìm beside lòmim (c) 'I break'. The latter accentuation recalls the Vedic loss of accent on finite verb forms in main clauses, e.g. á gamat 'may he come'.

As to Olander's rhetorical "final remark" on my "methodological approach" (212), it must be regretted that he does not draw the reader's attention to the fact that 
his "Proto-Slavic" phonological system (127) differs from my Early Slavic system (6.0) in the absence of a glottal stop which accounts for the rise and development of the new timbre and quantity distinctions, which he does not discuss. He also does not discuss the rise and development of the nasal vowels, nor of $* j$, which have considerable impact on the reconstruction of the phonological system. I am sorry that he has not replaced his confusing analysis in terms of "accent" and "ictus" by a consistent treatment in terms of High and Low tone, which could have avoided a number of misunderstandings. Had he done these things, he would probably have found very few substantial differences between his analysis and mine. But it is difficult to see how his mobility law could have survived the evidence of Slavic vowel length. As it is, Olander's free choice between "Proto-Indo-European" alternatives as input and his limitation of the Slavic evidence by excluding the new timbre and quantity distinctions as output enable him to explain almost any reconstructed word form, either as a regular phonetic reflex or as the result of influence from alternating forms. This is in stark contrast with my aim to explain the actual distribution of accent, tone and quantity as they are attested in the Slavic languages.

\section{$\mathrm{R}$ e f e r e n c e s}

Beekes 1985:

Beekes 1995:

Derksen 1996:

Derksen 2008:

Dybo 1962:

Dybo 1968:

Greenberg 2000:

Greenberg 2007:

van Helten 1891:

Illič-Svityč 1963:

Ivić 1958:

Ivić - Lehiste 1967:

Jurišić 1973:

Klaić 1936:
Robert S. P. Beekes, The origins of the Indo-European nominal inflection, Innsbruck

Robert S. P. Beekes, Comparative Indo-European linguistics: An introduction, Amsterdam

Rick Derksen, Metatony in Baltic, Amsterdam

Rick Derksen, Etymological dictionary of the Slavic inherited lexicon, Leiden

Vladimir A. Dybo, O rekonstrukcii udarenija v praslavjanskom glagole, Voprosy slavjanskogo jazykoznanija 6, 3-27

Vladimir A. Dybo, Akcentologija i slovoobrazovanie v slavjanskom. Slavjanskoe jazykoznanie: VI meždunarodnyj s"ezd slavistov, Praga 1968, Moskva, 148-224

Marc L. Greenberg, A historical phonology of the Slovene language, Heidelberg

Marc L. Greenberg, Phonetic evidence for the development of the "acute" tone in Slavic. Tones and theories, Proceedings of the international workshop on Balto-Slavic accentology, Zagreb, 75-87

W. L. van Helten, Grammatisches, Beiträge zur Geschichte der deutschen Sprache und Literatur 15, 455-488

Vladislav M. Illič-Svityč, Imennaja akcentuacija v baltijskom i slavjanskom: Sud'ba akcentuacionnyx paradigm, Moskva

Pavle Ivić, Die serbokroatischen Dialekte: Ihre Struktur und Entwicklung, The Hague

Pavle Ivić - Ilse Lehiste, Prilozi ispitivanju fonetske i fonološke prirode akcenata u savremenom srpskohrvatskom jeziku, Zbornik za Filologiju i Lingvistiku 10, 55-93

Blaž Jurišić, Rječnik govora otoka Vrgade II: Rječnik, Zagreb

A. Klaić, O podravskom akcentu i kvantitetu, Južnoslovenski Filolog $15,181-183$ 
Kloekhorst 2008:

Kortlandt 1976:

Kortlandt 1977:

Kortlandt 1978a:

Kortlandt 1978b:

Kortlandt 1980:

Kortlandt 1982:

Kortlandt 1983:

Kortlandt 1985a:

Kortlandt 1985b:

Kortlandt 1985c:

Kortlandt 1986:

Kortlandt 1987:

Kortlandt 1989a:

Kortlandt 1989b:

Kortlandt 1989c:

Kortlandt 1992:

Kortlandt 1993:

Kortlandt 1997a:

Kortlandt 1997b:

Kortlandt 2000:

Kortlandt 2001:

Kortlandt 2003a:

Kortlandt 2003b:

Kortlandt 2004:

Kortlandt 2005a:

Kortlandt 2005b:

Kortlandt 2006:
Alwin Kloekhorst, Etymological dictionary of the Hittite inherited lexicon, Leiden

Frederik Kortlandt, The Slovene neo-circumflex, The Slavonic and East European Review 54/1, 1-10

Frederik Kortlandt, Historical laws of Baltic accentuation, Baltistica 13/2, 319-330

Frederik Kortlandt, A history of Slavic accentuation, Lingua 44, 6791

Frederik Kortlandt, On the history of the genitive plural in Slavic, Baltic, Germanic, and Indo-European, Lingua 45, 281-300

Frederik Kortlandt, Zur Akzentuierung der Kiever Blätter, Zeitschrift für slavische Philologie 41/1, 1-4

Frederik Kortlandt, Sravnitel'no-istoričeskie kommentarii k bolgarskomu udareniju, Zbornik za Filologiju i Lingvistiku 25/1, 91-96

Frederik Kortlandt, On final syllables in Slavic, Journal of IndoEuropean Studies 11, 167-185

Frederik Kortlandt, Long vowels in Balto-Slavic, Baltistica 21/2, 112124

Frederik Kortlandt, Proto-Indo-European glottalic stops: The comparative evidence, Folia Linguistica Historica 6/2, 183-201

Frederik Kortlandt, Slavic imamb, International Journal of Slavic Linguistics and Poetics 31-32 [Fs. Birnbaum], 235-239

Frederik Kortlandt, Proto-Indo-European tones?, Journal of IndoEuropean Studies 14, 153-160

Frederik Kortlandt, The formation of the Old Prussian present tense, Baltistica 23/2, 104-111

Frederik Kortlandt, Od praindoevropskog jezika do slovenskog (fonološki razvoj), Zbornik za Filologiju i Lingvistiku 32/2, 41-58; English edition: From Proto-Indo-European to Slavic, www.kortlandt.nl

Frederik Kortlandt, Lithuanian statýti and related formations, Baltistica $25 / 2,104-112$

Frederik Kortlandt, Der polabische Wortakzent, Zeitschrift für slavische Philologie 49/1 (1989), 163-170

Frederik Kortlandt, The Aeolic optative. Rekonstruktion und relative Chronologie: Akten der VIII. Fachtagung der Indogermanischen Gesellschaft, Leiden 1987, Innsbruck, 235-239

Frederik Kortlandt, Tokie šalti rytai, Baltistica 28/1, 45-48

Frederik Kortlandt, PIE lengthened grade in Balto-Slavic, in: Festschrift for Eric P. Hamp II, Washington, 26-31

Frederik Kortlandt, Baltic $\bar{e}$ - and $\bar{\imath} / j \bar{a}$-stems, Baltistica $32 / 2,157-163$

Frederik Kortlandt, Old Prussian participles, Res Balticae 6, 69-75

Frederik Kortlandt, OPr. -snā, Lith. -sena, Latv. -šana, Mvnera lingvistica et philologica [Fs. Hasiuk], Poznań, 137-139

Frederik Kortlandt, Armeniaca: Comparative notes, Ann Arbor

Frederik Kortlandt, Early dialectal diversity in South Slavic II, Dutch contributions to the 13th international congress of slavists, Ljubljana: Linguistics (= Studies in Slavic and General Linguistics 30), 215-235

Frederik Kortlandt, Indo-Uralic consonant gradation. Etymologie, Entlehnungen und Entwicklungen [Fs. Koivulehto], Helsinki, 163170

Frederik Kortlandt, On the accentuation of the illative, Baltu Filologija 14/1, 67-69

Frederik Kortlandt, From Serbo-Croatian to Indo-European, Wiener slavistisches Jahrbuch 51, 113-130

Frederik Kortlandt, Balto-Slavic accentual mobility, Baltistica 41/3, 359-369 
Kortlandt 2007a: $\quad$ Frederik Kortlandt, Miscellaneous remarks on Balto-Slavic accentuation. Tones and theories: Proceedings of the international workshop on Balto-Slavic accentology, Zagreb, 229-235

Kortlandt 2007b: $\quad$ Frederik Kortlandt, Gothic gen.pl. $-e$. Historische Sprachwissenschaft 120, 237-240

Kortlandt 2008a: $\quad$ Frederik Kortlandt, Slavic historical morphology: Nominal paradigms. Dutch contributions to the 14th international congress of slavists, Ohrid: Linguistics (= Studies in Slavic and General Linguistics 34), 397-429

Kortlandt 2008b: Frederik Kortlandt, Balto-Slavic phonological developments, Baltistica 43/1, 5-15

Kortlandt 2009: $\quad$ Frederik Kortlandt, Accent retraction and tonogenesis. Stressing the past: Papers on Baltic and Slavic accentology (= Studies in Slavic and General Linguistics 35), 75-82

Kuiper 1942:

Langston 2007:

Franciscus B.J. Kuiper, Notes on Vedic noun-inflexion, Amsterdam Keith Langston, Common Slavic accentual paradigm (d): A reevaluation of evidence from Čakavian. Tones and theories: Proceedings of the international workshop on Balto-Slavic accentology, Zagreb, 121150

Lubotsky 1981: $\quad$ Alexander Lubotsky, Gr. $\pi \dot{\eta} \gamma v v \mu \imath$ : Skt. pajrá- and loss of laryngeals before mediae in Indo-Iranian, Münchener Studien zur Sprachwissenschaft 40, 133-138

Lubotsky 1988: $\quad$ Alexander Lubotsky, The system of nominal accentuation in Sanskrit and Proto-Indo-European, Leiden

Lubotsky 1989: $\quad$ Alexander Lubotsky, Against a Proto-Indo-European phoneme *a. The new sound of Indo-European: Essays in phonological reconstruction, Berlin, 53-66

Lubotsky 1990 : $\quad$ Alexander Lubotsky, La loi de Brugmann et ${ }^{*} H_{3} e-$. La reconstruction des laryngales, Paris, 129-136

Olander 2006:

Olander 2009:

Pedersen 1926 :

Pedersen 1933:

Pronk 2009:

Seržants 2004:

Thomas Olander, Accentual mobility: The prehistory of the BaltoSlavic mobile accent paradigms, Diss., Copenhagen

Thomas Olander, Balto-Slavic accentual mobility, Berlin

Holger Pedersen, La cinquième déclinaison latine, København

Holger Pedersen, Études lituaniennes, København

Tijmen Pronk, The Slovene dialect of Egg and Potschach in the Gailtal, Austria, Diss., Leiden

Ilja Seržants, Einige Bemerkungen zur Geschichte des Illativs, Baltu Filologija 13/1, 113-120

Stang 1952:

Stang 1957:

Steensland 1973:

Christian S. Stang, Eine Bemerkung zur slowakischen Präsensflexion, Norsk Tidsskrift for Sprogvidenskap 16, 271-275

Christian S. Stang, Slavonic accentuation, Oslo Šaxmatov 1915: $\quad$ Aleksej A. Šaxmatov, Očerk drevnějsago perioda istorii russkago jazyka, Petrograd

Topolińska 1961: Zuzanna Topolińska, Z historii akcentu polskiego od wieku XVI do dziś, Wrocław

Ter-Avanesova 1989: Aleksandra V. Ter-Avanesova, Ob odnoj slavjanskoj akcentnoj innovacii. Slavjanskoe i balkanskoe jazykoznanie: Prosodija, Moskva, 216-250

Vanags 1994: Pēteris Vanags, Die Entwicklungstendenzen der Kasusendungen in den ältesten lettischen Sprachdenkmälern, Linguistica Baltica 3, 121130

Vermeer 1985: $\quad$ Willem Vermeer, Non-initial falling tones in neo-štokavian dialects, Zbornik za Filologiju i Lingvistiku 27-28 [Fs. Ivić], 143-149 
Vermeer 1991: Willem Vermeer, The mysterious North Russian nominative singular ending $-e$ and the problem of the reflex of Proto-Indo-European *-os in Slavic, Die Welt der Slaven 36, 271-295

Vermeer 1992: Willem Vermeer, In the beginning was the lengthened grade: On the continuity of Proto-Indo-European vowel quantity in Slavic. Rekonstruktion und relative Chronologie: Akten der VIII. Fachtagung der Indogermanischen Gesellschaft, Leiden 1987, Innsbruck, 115-136

Wackernagel 1896: Jakob Wackernagel, Altindische Grammatik I: Lautlehre, Göttingen

A b stract: Balto-Slavic accentuation revisited. There is every reason to welcome the revised edition (2009) of Thomas Olander's dissertation (2006), which I have criticized elsewhere (Baltistica 41/3). It must be hoped that the easy access to a complex set of problems which this book offers will have a stimulating effect on the study of Balto-Slavic accentology.

However, what the author evidently regards as his main result, the "mobility law", cannot be accepted because it is incompatible with the data. The origin of the mistaken analysis which has resulted in Olander's "mobility law" must be sought in his reconstructions of Proto-Indo-European and Proto-Slavic. His "mobility law" is irreconcilable with the quantitative reflexes of vowels and diphthongs in Slavic. The same holds for his early date of Dybo's law. Olander omits a large and essential part of the evidence.

While I am happy to see that Olander has accepted my view that the Balto-Slavic acute can be identified as glottalization, I am sorry that he has not (yet) seen why glottalized vowels must have remained distinct from earlier long vowels in Slavic. I am glad to see that Olander has accepted my derivation of $-\bar{l}$ - from athematic $*-e i$ - in the Slavic $i$-presents.

As a result of Olander's erroneous assumption that "after Dybo's Law the glottalisation disappeared and long glottalised vowels merged with long non-glottalised vowels", he is unable to explain the numerous formations where Dybo's law introduced new long vowels in pretonic syllables. Olander ignores the fact that PIE lengthened grade vowels are never acute and (unlike the acute vowels) did not lose their length when the new timbre distinctions arose in Slavic.

As a result of Olander's mobility law, end-stressed word forms became "unaccented" and received an automatic Low tone "ictus", either on the final syllable before an enclitic particle or (if there was none) on the first proclitic element or initial syllable of the phonological word. This is a peculiar compromise satisfying neither the Slavic mobility between pre-phrasal and phrase-final syllables nor the Lithuanian mobility between pre-radical and word-final syllables. One cannot escape the impression that Olander's reconstruction of "Proto-Indo-European" endings is strongly influenced by the outcome of his mobility law.

Olander's interpretation of Meillet's law cannot be correct because the prosodic merger of acute and circumflex in Slavic was limited to pretonic and post-posttonic syllables while the distinction between acute and non-acute was preserved under the stress and in the first posttonic syllable, where it is reflected as short versus long in the historical languages. My chief objection is not the typological improbability of Olander's mobility law but the fact that it is contradicted by the evidence.

In my view, generalization of the Low tone of pretonic syllables to barytone forms of mobile accent paradigms gave rise to Olander's "unaccented word-forms" with distinctive Low tone on the initial syllable. This introduction of a distinctive Low tone is an essentially syntactic development with a perfect analogue in Vedic. The Low tone had a falling contour after a preceding High tone, as a result of which the High tone received a rising contour after a preceding Low tone. At a later stage, the rising contour shifted the High tone to the following syllable (Dybo's law). In Slovene, the distinctive Low tone became High when the falling contour shifted to the right while the High tone became Low. The rise of a distinctive Low tone was not an automatic consequence of the retraction of the stress to a preposition or prefix.

It must be regretted that Olander does not draw the reader's attention to the fact that his "Proto-Slavic" phonological system differs from my Early Slavic system in the absence of a glottal stop which accounts for the rise and development of the new timbre and quantity distinctions, which he does not discuss. He also does not discuss the rise and development of the nasal vowels, nor of $* j$, which have considerable impact on the reconstruction of the phonological system. I am sorry that he has not replaced his confusing analysis in terms of 
"accent" and "ictus" by a consistent treatment in terms of High and Low tone, which could have avoided a number of misunderstandings. Olander's free choice between "Proto-IndoEuropean" alternatives as input and his limitation of the Slavic evidence by excluding the new timbre and quantity distinctions as output enable him to explain almost any reconstructed word form, either as a regular phonetic reflex or as the result of influence from alternating forms. This is in stark contrast with my aim to explain the actual distribution of accent, tone and quantity as they are attested in the Slavic languages.

K e y w or d s: Baltic, Slavic, accent, mobility

Frederik Kortlandt

Cobetstraat 24

2313 KC Leiden, Niederlande

www.kortlandt.nl 
